\title{
SOCIALIZATION: A KEY CONCEPT IN SOCIAL SCIENCES
}

\author{
Carlos Miguel Ferreira ${ }^{1}$, Sandro Serpa ${ }^{2 \star}$ \\ ${ }^{1}$ Prof. Dr., Interdisciplinary Centre of Social Sciences - CICS.NOVA; PORTUGAL, \\ carlosmiguelferreira32@gmail.com \\ ${ }^{2}$ Prof. Dr., University of the Azores, Faculty of Social and Human Sciences, Department of \\ Sociology; Interdisciplinary Centre of Social Sciences - CICS.UAc/CICS.NOVA.UAc; \\ Interdisciplinary Centre for Childhood and Adolescence - NICA - UAc, PORTUGAL, \\ sandro.nf.serpa@uac.pt \\ ${ }^{*}$ Corresponding Author
}

\begin{abstract}
The concept of socialization is widely used in the field of social studies. But what is the importance of socialization to Social Science? To seek to offer answer to this question, a bibliographical search on socialization was carried out. Furthermore, our experience in the teaching of social sciences, especially of Sociology, was also used. It is concluded that, despite the plethora of definitions of socialization, this process of formation of the social human is a key concept in Sociology and in the remaining Social Sciences, by allowing the interconnection between society and culture.
\end{abstract}

Keywords: socialization, sociability, culture, society, Sociology, Social Sciences.

\section{INTRODUCTION}

The concept of socialization is present, in diverse forms and with different meanings, both in the specific area of Sociology (general or in its specializations) (Giddens, 1997; Abrantes, 2011, 2013; Pimentel, 2012; Vincent, Lahire, \& Thin, 1994; Dubar, 1997), and also in other scientific fields of Social Sciences (Abrantes, 2013; Rego et al., 2015).

Besides being a continuous process (Pena Pires, 2012; Brownell, \& The Early Social Development Research Lab, 2016) which is fundamental to providing social order and predictability (within certain limits): "Socialization begins at birth, operates bidirectionally during routine interactions, and assumes many forms, both subtle and complex. Socialization of prosociality does not take effect only when a child is already prosocial and begins to comprehend social norms, as some have argued. Instead, social influences during infancy gradually give rise to cooperative, caring motives and behavior. Although scholars who maintain that prosocial dispositions, behaviors, or concepts are innate may not entirely rule out a role for social experience, progress in explaining the ontogenetic origins of prosociality depends on specifying more fully the socialization mechanisms beginning in infancy. Human prosocial behaviour likely evolved to be acquired by infants developing in human social environments in concert with other codeveloping systems" (Brownell, \& The Early Social Development Research Lab, 2016, pp. 225 and 226).

When the topic of socialization is addressed, various types emerge, such as social, organizational, professional, primary, secondary, anticipatory socialization and resocialization - among other names and meanings -, formal or non-formal, which contributes to some polysemy of the basic concept - socialization. 
In addition to be a continuous process, the concept of socialization is widely mobilized in social studies (Höppner, 2017; Silva \& Pinto, 1986; Setton, 2010; Abrantes, 2016; Paiva, 2014). For example, organizational socialization is critical, inasmuch as: "Socialization mechanisms allow employees to be active participants in the information exchange process and function as both receivers (beliefs and superior mentoring) and senders of information (peer mentoring). Through participation in the information exchange process employees gain knowledge on what the organization values, which facilitates goal congruence" (Kennedy \& Widener, 2019, p. 2).

According to Cuche (1999), the concept of socialization started to be commonly used from the 1930s onwards, referring, in general, to how the individual becomes a member of a society, identifying with it. However, the question arises: what is the importance of socialization for Social Science?

Socialization is a universal process, with specificities in each context (Pinto, 1995; Ferreira \& Serpa, 2017; Haecht, 1994; Serpa, 2018) and it is sometimes misunderstood as sociability or sociality by common sense (Valade, 1990). However, this process is often severely criticised by several authors for its heuristic (in)capacity, as, for example, Abrantes (2013), Höppner (2017) and Grigorowitschs (2008) remind us. The latter author argues that: "the processes of socialization concept thus defined allows to grasp the tensions and contradictions of life in society, both in childhood and in adult life, without tipping either towards the sheer reproduction and maintenance of social order, or towards the total autonomy of individual action" (Grigorowitschs, 2008, p. 49).

In turn, Lahire (2011) advocates that: "Family, through which each individual learns to discover the social world and to find his/her place, is the first (primary) space that tends to objectively establish - without knowing or intending it - the limits of the possible and of the desirable. The subjective assessment of the prospects of attaining this or that social position, these or those material or symbolic resources, has no conscious calculation whatsoever, nor is it clearly the solution for a problem of probability" (p. 14).

\section{METHODS}

The research question that gears this conceptual paper is as follows: What is the importance of socialization for Social Science? A document collection and analysis was carried out by title of the term "socialization" plus "sociology" in Abstract on January 15, 16 and 17, 2019, on B-ON (ON (Biblioteca do Conhecimento Online Online Knowledge Library), which makes unlimited and permanent access available by research and higher education institutions to full texts of scientific journals and other publications (Biblioteca do conhecimento online, n.d.).

\section{SOCIALIZATION}

While the concept of socialization has, sometimes, negative connotations, it has been and is explicitly present and is central in problematizing perspectives of reality, such as, for example, the ones by Durkheim, Weber, Simmel, Mead, Piaget, Parsons, Merton, Bourdieu, Habermas, Berger and Luckman, and Luhmann and Lahire, among many others (Grigorowitschs, 2008; Dubar, 1997; Abrantes, 2013).

According to Rocher (1989), a fundamental axiom of Sociology is: "human action is sociable because it is part of a structure of action that is provided to it by collective or common norms or rules in which it should be inspired" (p. 41), which results from the socialization processes.

Socialization is what allows human beings to develop in their potential wholeness (Höppner, 2017), inasmuch as: "it is the development of language, thought and rationality that makes us persons, with the ability to interpret and act on the surrounding environment" (Abrantes, 2011, p. 123).

To a certain extent, the socialization process somehow naturalises collective situations and also the individual's pre-dispositions and behaviours (Setton, 2010). There has always been a tension in how to consider socialization (Cherkaoui, 1990, Setton, 2009). As argued by Setton (2009): "this process can be thought from two points of view: either as imposition of standards on individual conduct, being often defined as a process of conditioning and control of society over individuals; or as a process of attainment of knowledge and learning, internalization of patterns of conduct that make them more human and civilized" ( $p$. 297).

\subsection{Transmissive Perspective}

Already in the emergence of the institutionalization of Sociology as a fully acknowledged scientific discipline, socialization (or rather, moral "education") was a guiding concept of the proposal of one of the founders of Sociology, Émile Durkheim (1893/1977, 1895/1998), for example, in the concept of anomie (Serpa \& Ferreira, 2018a), who considered that the individual is somewhat "born" from society (Aron, 1994). In The 
Rules of the Sociological Method, Durkheim considered Sociology as an: "institution to all beliefs and to all modes of behaviour instituted by the collectivity; Sociology can thus be defined as: the science of institutions, their genesis and their functioning" (Braga da Cruz, 1989, p. 311). Furthermore, in The Division of Social Work, Durkheim sustained that; "man is only a moral being because he lives in society, insofar as morality consists of being in solidarity with a group and varies with this solidarity. Let all social life disappear, and the moral life will also disappear because it no longer has an object to be bound to" (Braga da Cruz, 1989, p. 335).

The process of socialization is, according to Rocher's (1989) stance, the: "process by which throughout life the human person learns and internalises the sociocultural elements of his/her environment, integrates them into the structure of his/her personality under the influence of experiences of significant social agents and thus adapts to the social environment in which one should live" (p. 126).

Although there are several definitions of culture as a historical and polysemic concept (Cuche, 1999; Serpa, 2016a, 2016b; Rivière, 1990; Segrestin, 1990), and assuming the influence of Durkheim and Rocher, from our standpoint (Serpa, 2016b), culture may be considered as the ways of thinking, feeling and acting shared by a group of individuals and that are learned and understood through the socialization processes. In this logic, "Culture and society are found in each individual and each individual is incorporated into the social organization" (Rocher, 1989, p. 124), and there is a close relationship between social hierarchies and cultural hierarchies (Cuche, 1999).

It is this notion of culture attainment that allows a naturalization of the world. For example, "Be 'natural', an expression often repeated to children, particularly in the bourgeoisie milieus, means, in fact, "Be in accordance with the model of culture that has been conveyed to you" (Cuche, 1999, p. 24).

However, and to some extent, as all culture ultimately consists of a permanent process of transformation and variations over time (Segrestin, 1990; Cuche, 1999), Cuche (1999, p. 107) proposes that it is perhaps preferable to replace the term culture with that of "culturation" given the dynamics it entails.

In the contemporary world, the aforementioned dynamics is, perhaps, more pronounced considering the existence of a growing number and more varied socialization agents (Abrantes, 2011, 2013, 2016). Furthermore, as Setton (2011) reminded us, "the socialization process of today's societies is a plural space of multiple identity references" (p. 713).

In summary, this approach to the transition from a more transmissive socialization to a more constructivist socialization is clearly explained by Diogo (2008). The author argues that: "the process by which an individual internalizes norms, values, attitudes, roles and the knowledge of the social group where he/she was born and where he/she belongs, guaranteeing the individual's adaptation to society and, simultaneously, the functioning and integration of society [...] socialization is a process of social construction [...] while, in the transmissive perspective, the unit of the social world stands out, in the constructive perspective, the social actors are confronted with a plurality of logics of action" (pp. 65 and 66).

\subsection{Constructivist Perspective}

Regarding the more deterministic approach of socialization and as opposed to it, there is a more constructivist approach (we will call it this way in this paper, although this designation is not unanimous among the scientific community). "To this deterministic stance, a more flexible conception can be opposed, which takes into account the relative autonomy of the individual, his/her ability to adapt the attained dispositions to the situations experienced, and even to modify when necessary the norms and values internalized according to certain problems which he/she needs to solve" (Cherkaoui, 1990, p. 227).

As Giddens (1997) points out about social and cultural regularities and reproduction, "our actions are influenced by the structural features of the societies where we are brought up and live in, which, at the same time, we re-create (and, to some extent, we change) with our own actions" (p. 32). This allows inferring that culture and society do not exist without one another. Society - a "system of interrelations that bind individuals together" (Giddens, 1997, p. 47) - is only possible through socialization, insofar as culture is what makes us human, with the creation of an awareness of a "social-self" (Giddens, 1997, p. 871) and enables the existence of common expectations: "socialization is also at the origin of our own individuality and freedom. Throughout socialization, each of us develops a sense of self-identity and the ability to act and think independently" (Giddens, 1997, p. 110).

As Grigorowitschs (2008) and Javeau (1998) maintain, the socializing process is dynamically interactive. According to Javeau (1998), "it is above all making one capable of autonomously assessing situations one is faced with and of discovering, in one's repertoire of scenes to perform, the ones that best apply to this or that specific situation" (p. 166). The author adds that one "socializes at the same time that one is socialized, one 
builds oneself up to the extent that one is built by others" (p. 167).

Socialization is the process that enables the formation and reformulation of the individual's identity (Grigorowitschs, 2008). According to Dubar (1997), as summarised here, "If the biographical process may be defined as a construction in time by individuals of social and professional identities on the basis of the categories offered by successive institutions (family, school, labour market, company...) and considered simultaneously accessible and valuing ("subjective" transaction), the relational process refers to the acknowledgement, at a given moment and within a given space of legitimation, of the identities associated with knowledge, competencies and self-images proposed and expressed by individuals in the systems of action. The articulation of these two processes represents the projection of the identity space-time of a generation confronted with the others in its biographical path and its spatial development. The social forms of this articulation are, at the same time, the matrix of categories that structure the space of social positions (high/low but also inside/outside employment) and the temporality of social trajectories (stability/mobility but also continuity/rupture)" (p. 118).

In turn, according to Setton (2009), there are, today, multiple identity references. Abrantes (2011) posits that this process of identity construction is very complex and puts forth several reasons: "socialization is neither only the construction of identities, entailing the development of dispositions, languages, competencies [...]; nor are identities only the product of successive socializations (including also genetic factors and material conditions)" (p. 132). Still according to Abrantes (2013), in developing his proposal on socialization, there are three interconnected principles: "(1) any individual's life repertoire of experiences is a singular fraction of "the social" (objective principle); (2) enrolment in each of those experiences partially depends on individual's abilities and motivations at each moment (subjective principle); (3) the information produced by such experiences cannot be fully stored and used, implying (inter-subjective) processes of selection, generalization and analogy (constructivist principle)" (p. 394).

The understanding of the socialization processes involves interdisciplinary cooperation (Abrantes, 2016; Serpa, Ferreira, \& Santos, 2017), insofar as "recent developments seem to point rather towards a multiplicity of dispositional systems, in constant interaction, but with clear tensions between them, and their harmonization is a work, always precarious and a posteriori, carried out by the self' (Abrantes, 2016, p.16).

Offering the example of Sociology as a "science that studies the (dis)order of the social world, and that deals with interactions, what results from interaction and has implications in this interaction between human beings, such as objects, practices, representations and values, inserting them into their social context" (Serpa \& Ferreira, 2018b, p. 841), common expectations emerge, to a large extent, from socialization processes (Cherkaoui, 1990; Serpa, 2018; Ferreira \& Serpa, 2018). In fact, as Ferreira and Serpa (2018) argue about the socialization processes: "as the active attainment of culture (composed of material and immaterial elements that are commonly shared by a broad set of individuals, a society, and that allow the existence of common expectations among individuals in their social relationship)" (p. 24).

\section{CONCLUSION}

This study provides a perspective in understanding that people are, necessarily at the same time, social and cultural beings (Silva, 1986; Grigorowitschs, 2008) and, to some extent, nature and biology are conditioned by culture and lead to "the conversion of the actors' objective probabilities into subjective expectations" (Silva, 1986, p. 35).

It is concluded that, notwithstanding the wide array of definitions of socialization, this process of formation of the social human is a key concept in Sociology and in the remaining Social Sciences, by allowing to link society and culture. It is a process in permanent (re)construction.

This basic idea does not prevent the acknowledgement of the need to deepen the (inter)relationship between socialization and biology (such as, for example, neuroscience), as exemplified by Abrantes (2016) and Höppner (2017).

\section{ACKNOWLEDGMENT}

We would like to thank to the Editor and Reviewers for their comments and suggestions.

\section{NOTE}

A similar version of this paper was published in: Ferreira, C. M., \& Serpa, S. (2019). Socialization: a key concept in Social Sciences. Abstracts \& Proceedings of SOCIOINT 2019 - 6th International Conference on Education, Social Sciences and Humanities, 24-26 June 2019, pp. 691-697. İstanbul, Turkey: OCERINTInternational Organization Center of Academic Research. 


\section{FUNDING}

University of Azores, Interdisciplinary Centre of Social Sciences-CICS.UAc/CICS.NOVA.UAc, UID/SOC/04647/2013, with the financial support of the FCT/MEC through national funds and when applicable co-financing from the FEDER under the PT2020 Partnership Agreement.

\section{REFERENCE LIST}

Abrantes, P. (2011). Para uma teoria da socialização [For a theory of socialization]. Sociologia - Revista da Faculdade de Letras da Universidade do Porto, 21, 121-139.

Abrantes, P. (2013). Opening the black box of socialization: Emotions, practices and (biographical) identities. International Journal of Sociology and Anthropology, 5(9), 391-401. https://doi.org/10.5897/ijsa2013.0484.

Abrantes, P. (2016). Socialização: Onde a sociologia e as neurociências se encontram [Socialization: Where sociology and neurosciences meet]. Sociologia, Problemas e Práticas, 82. https://doi.org/10.7458/spp2016826609.

Aron, R. (1994). Émile Durkheim. In As etapas do pensamento sociológico [The stages of sociological thinking] (pp. 311-392). Lisboa: Publicações Dom Quixote.

Biblioteca do conhecimento online (s.d.). What is b-on? Available at https://www.b-on.pt/en/what-is-b-on/. Accessed on January 17, 2019.

Braga da Cruz, M. (1989). Teorias sociológicas. Os fundadores e os clássicos (Antologia de textos) (I Vol.) [Sociological theories. The founders and the classics (Anthology of texts) (I Vol.)]. Emile Durkheim, pp. 297-400. Lisboa: Fundação Calouste Gulbenkian.

Brownell, C. A., \& The Early Social Development Research Lab (2016). Prosocial behavior in infancy: The role of socialization. Child Development Perspectives, 10(4), 222-227. doi:10.1111/cdep.12189.

Cherkaoui, M. (1990). Socialização [Socialization]. In R. Boudon, P. Besnard, M. Cherkaoui, \& B.-P. Lécuyer (Dirs.), Dicionário de sociologia [Dictionary of sociology] (p. 227). Lisboa: Publicações Dom Quixote.

Cuche, D. (1999). A noção de cultura nas ciências sociais [The concept of culture in social sciences]. Lisboa: Fim de Século.

Diogo, A. M. (2008). Investimento das famílias na escola. Dinâmicas familiares e contexto escolar local [Families' investment in school. Family dynamics and local school context]. Lisboa: Celta Editora.

Dubar, C. (1997). A socialização. Construção das identidades sociais e profissionais [Socialization. Building social and professional identities]. Porto: Porto Editora.

Durkheim, E. (1893/1977). A divisão do trabalho social [The division of social work]. Lisboa: Editorial Presença.

Durkheim, E. (1895/1998). As regras do método sociológico [The rules of the sociological method]. Lisboa: Editorial Presença.

Ferreira, C. M., \& Serpa, S. (2017). Challenges in the teaching of Sociology in higher education. Contributions to a discussion. Societies - Special Issue Training Models and Practices in Sociology, 7(4), 30, 1-11. doi:10.3390/soc7040030.

Ferreira, C. M., \& Serpa, S. (2018). Imitation in socialization processes. A perspective about Gabriel Tarde. Proceedings of the 6th HASSACC 2018 - Academic Online Conference Interdisciplinary Approaches in Human and Social Sciences, September 24-30. https://doi.org/10.18638/hassacc.2018.6.1.260.

Giddens, A. (1997). Sociologia [Sociology]. Lisboa: Fundação Calouste Gulbenkian.

Grigorowitschs, T. (2008). O conceito "socialização" caiu em desuso? Uma análise dos processos de socialização na infância com base em Georg Simmel e George H. Mead [ls the "socialization" concept outdated? An analisis of the socialization processes in childhood according to Georg Simmel and George H. Mead]. Educação \& Sociedade, 29(102), 33-54. https://doi.org/10.1590/s0101- 


\section{3.}

Javeau, C. (1998). Lições de sociologia [Lessons of sociology]. Oeiras: Celta Editora.

Kennedy, F. A., \& Widener, S. K. (2019). Socialization mechanisms and goal congruence. Accounting, Organizations and Society. doi:10.1016/j.aos.2019.01.004.

Lahire, B. (2011). A transmissão familiar da ordem desigual das coisas [The familiar transmission of the unequal order of things]. Sociologia, Revista da Faculdade de Letras da Universidade do Porto, Vol. XXI, 13-22.

Haecht, A. V. (1994). A escola à prova da sociologia [The sociology-proof school]. Lisboa: Instituto Piaget.

Höppner, G. (2017). Rethinking socialization research through the lens of new materialism. Frontiers in Sociology, 2. https://doi.org/10.3389/fsoc.2017.00013.

Paiva, A. (2014). Pensamento sociológico. Uma introdução didática às teorias clássicas [Sociological thinking. A didactic introduction to classical theories]. Lisboa: PACTOR: Edições de Ciências Sociais, Forenses e da Educação.

Pena Pires, R. (2012). O problema da ordem [The problem of order]. Sociologia, Problemas e Práticas, (69). doi:10.7458/spp201269785

Pimentel, D. (2012). Sociologia da empresa e das organizações. Uma breve introdução a problemas e perspectivas [Sociology of the company and organizations. A brief introduction to problems and perspectives]. Lisboa: Escolar Editora.

Pinto, C. A. (1995). Sociologia da escola [Sociology of school]. Lisboa: McGraw-Hill.

Rego, A., Cunha, M. P., Gomes, J. F. S., Cunha, R. C., Cabral-Cardoso, C., \& Marques, C. A. (2015). Manual de gestão de pessoas e do capital humano [Manual of people and human capital management]. Lisboa: Edições Sílabo.

Rivière, C. (1990). Cultura [Culture]. In R. Boudon, P. Besnard, M. Cherkaoui, \& B-P. Lécuyer (Dirs.), Dicionário de sociologia [Dictionary of sociology] (pp. 62-63). Lisboa: Publicações Dom Quixote.

Rocher, G. (1989). Sociologia geral. A acção social. Vol I [General sociology. Social action. Vol.I]. Lisboa: Editorial Presença.

Segrestin, D. (1990). Aculturação [Aculturation]. In R. Boudon, P. Besnard, M. Cherkaoui, \& B-P- Lécuyer (Dirs.), Dicionário de sociologia [Dictionary of sociology] (pp. 12-13). Lisboa: Publicações Dom Quixote.

Serpa, S. (2016a). Organization as an analytical level for investigation organizational culture. The Social Sciences, 11(13), 3257-3263. doi: 10.3923/sscience.2016.3257.3263. Available at http://medwelljournals.com/abstract/?doi=sscience.2016.3257.3263.

Serpa, S. (2016b). An overview of the concept of organisational culture. International Business Management, 10(1), 51-61. Available at http://medwelljournals.com/abstract/?doi=ibm.2016.51.61

Serpa, S. (2018). A reflection on sociology of education. International Journal of Social Science Studies, 6(3), 33-39. https://doi.org/10.11114/ijsss.v6i3.3013.

Serpa, S., \& Ferreira, C. M. (2018a). Anomie in the sociological perspective of Émile Durkheim. Sociol Int J., 2(6), 689-691. doi: 10.15406/sij.2018.02.00121.

Serpa, S., \& Ferreira, C. M. (2018b). Sociological problem and social problem: Contributions to a discussion. Sociology and Anthropology, 6(11), 840-844. https://doi.org/10.13189/sa.2018.061104.

Serpa, S., Ferreira, C. M., \& Santos, A. I. (2017). Fostering interdisciplinarity: Implications for social sciences. International Journal of Social Science Studies, 5(12), 44. https://doi.org/10.11114/ijsss.v5i12.2775.

Setton, M. G. J. (2009). A socialização como fato social total: Notas introdutórias sobre a teoria do habitus [Socialization as a total social fact: Introductory notes on the theory of habitus]. Revista Brasileira de Educação, 14(41), 296-307. https://doi.org/10.1590/s1413-24782009000200008.

Setton, M. G. J. (2010). Processos de socialização, práticas de cultura e legitimidade cultural [Socialization processes, culture practices and cultural legitimacy]. Estudos de Sociologia, Araraquara, 15(28), 1935. 
Setton, M. G. J. (2011). Teorias da socialização: Um estudo sobre as relações entre indivíduo e sociedade [Socialization theories: A study on the relationships between individual and society]. Educação e Pesquisa, 37(4), 711-724. https://doi.org/10.1590/s1517-97022011000400003.

Silva, A. S. (1986). A ruptura com o senso comum nas ciências sociais [The rupture with common sense in social sciences]. In A. S. Silva, \& J. M. Pinto (Orgs.), Metodologia das ciências sociais [Methodology of social sciences] (pp. 29-53). Porto: Edições Afrontamento.

Silva, A. S., \& Pinto, J. M. (1986). Uma visão global sobre as ciências sociais [An overview of social sciences]. In A. S. Silva, \& J. M. Pinto (Orgs.), Metodologia das ciências sociais [Methodology of social sciences] (pp. 9-27). Porto: Edições Afrontamento.

Valade, B. (1990). Sociabilidade [Sociability]. In R. Boudon, P. Besnard, M. Cherkaoui, \& B-P. Lécuyer (Dirs.), Dicionário de sociologia [Dictionary of sociology] (pp. 225-226). Lisboa: Publicações Dom Quixote.

Vincent, G., Lahire, B., \& Thin, D. (1994). Sur l'histoire et la théorie de la forme scolaire [On the history and theory of the school form]. In G. Vincent (Dir.), L'éducation prisonnière de la forme scolaire? [Education trapped in the school form?] (pp. 11-48). Lyon: Presses Universitaires de Lyon. 